Боне Величковски

\title{
КРАТОК ПРЕГЛЕД НА ТЕОРИИТЕ ВО ФОЛКЛОРИСТИКАТА ОД ДЕНЕШНА ПЕРСПЕКТИВА
}

\begin{abstract}
Апстракт: Во трудот авторот го насочува своето внимание кон проследувањето на она што се случуваше во областа на хуманистичките науки последните декади од XX век, а што беше обележано со нова, можеби, најтешка криза на позитивизмот и како време на напуштање на „големите теории“ и универзалните толкувачки шеми со краток преглед на актуелната состојба во фолклористиката и сродните дисциплини во светот.

Идентификувањето на сличностите и совпаѓањата во антрополошките, етнолошките и фолклористичките трудови му отстапи место на приоритетот во барањето на оригинални толкувања и на „локалното знаење“, а посебно внимание беше посветено на методологијата, сопствените претпоставки и размислувања во однос на истражувачката оптика. Линеарното гледиште на културните феномени се смени со појавата на динамичните врски меѓу сите чинители на сложениот мрежен систем.

Се појави една нова ера на чистење од „идеолошки очила“ и апологија на „новата фолклористика“ на крајот од минатиот век, која се одрази и врз домашното хуманистичко знаење. Бегството од цензура, напуштањето на воспоставените пристапи и познатите модели на толкување станаа плодна почва за појава на свежи теми и перспективи на истражување, откривајќи ја реалноста од нетривијалната страна.
\end{abstract}

Клучни зборови: теории, теоретизација, хуманистичките науки, антропологија, фолклористика.

Намерата на авторот не е да репродуцира некоја историја на теории во антропологијата, ниту да рангира теории по некој посебен редослед и во крајна линија, да бара предимство на една над која било друга. Во однос на антрополошките теории, сведоци сме дека нема недостаток од прирачници на оваа тема, како што се вовед во теоријата, историјата и збирките со анотирани антрополошки и фолклористички текстови. Намерата не оди во насока да се наведуваат теориски трудови, кои аргументираат и промовираат одреден теоретски проект во однос на другите. Наместо тоа, ова е краток осврт на теоретизирањето, обид да се истражи што се подразбира под „антрополошка теорија“ во врска со теориите што ги користат антрополозите, да се проследи оваа цел во рамките на дискурсот што се однесува на антропологијата во поширок контекст, пред сѐ, во трудовите на американските истражувачи, од половината на XX век, попрецизнао од 1965 до 2007 година, период доволно долг за да се овозможи идентификација на некои значајни линиски отстапки.

Подемот на антрополошката теорија на Марвин Харис (Harris, 1969), го доведе во прашање интегритетот на антрополошката теорија. Таа книга е 
огромен опус со сите антрополошки теории што постојат уште од Просветителството, од гледна точка на културниот материјализам и секоја теорија се мери како успех или неуспех против идеалната точка омега на она што Џонатан Фридман (Friedman, 1974, 444) подоцна требаше да го опише како „вулгарен материјализам“ на Харис.

На чуден начин, овој симплистички и селективен пристап му дозволува на Харис да понуди „едностран“ или „еднонасочен“ извештај за еволуцијата на теоријата и иако постојат разлики во нагласката и редот, стандардните истории на антрополошката теорија меѓу, да речеме, 1850 и 1970 г., генерално се претставени на овој начин. Во целина, една лекција што е научена од новите истории на темата иницирана од Стокинг (Stocking, 1968) е дека ретроспективните обиди на антрополозите „презентисти“ да ја периодизираат интелектуалната историја како многу други последователни и меѓусебно ексклузивни парадигми (еволуционизам, проследен од дифузионизам, по кој доаѓа функционализмот итн.) се прилично неубедливи кога ќе се подложат на поблизок увид.

По 60-тите години од дваесеттиот век, на почетокот дојде до теоретски бум на општествените и хуманистичките науки - настана разноликост во теоретизацијата и се доби чувство дека теоретизацијата е можеби највисоката форма на интелектуална активност, што му беше дотогаш позната на човештвото. Групата „Теоретска археологија“ е основана во 1977 година и е одговор на наводната атеоритичност на темите на истражување од средината на 60-тите години на дваесеттиот век, во обид да ја имитира социокултурната антропологија, што отворено го признаа нејзините основачи. Но, ова свртување, како што забележа Брус Тригер (Trigger, 2006), имало тенденција да ја репродуцира фрагментацијата и сектаријанизмот на социокултурните теории, при што теоретичарите биле заробени во одделни некомуникативни дискурси (Hodder, 2003). Кога малку повеќе ќе се осврнеме на ова, ќе се види дека повеќе се барало полемичко внимание и намерен култ на еретичка догма отколку сериозно тестирање на идеи. И во антропологијата и во археологијата постоела вистинска мешавина на тврдења (голем дел од тоа е неприфатен), предводена од Шели Ортнер (Ortner, 1984, 126), наоѓајќи одsив и кај Лои (Lowie, 1920, 33), за да го окарактеризира како „нешто составено од парчиња и закрпи“. Тоа беше тешка задача. И покрај сѐ, оваа анархија на идеи, со нејзините спротивставени идеолошки уверенија, се чинеше дека одразува вистинска фрустрација со сиромаштијата на мислата во темите. Најочигледен и епистемиолошки далекусежен развој во оваа криза на контрадикторно теоретизирање, дискредитирање и поткопување на „стабилните“ парадигми, а што доведува до „губење на визијата“, би се кажало, е неуспех на самиот „проект за социјална наука“, на позитивистичките закони и на предизвиците на „социјалната антропологија“.

Ова беше постигнато делумно преку постмодерната критика, особено преку симплистичката наука наспроти антинаучните тврдења, во која науката стана „метанаративна“ за да се третира со неверување и со теорија со скептицизам (Reyna, 2001, 10). Многумина беа убедувани да ја избегнуваат целокупната теорија или барем да ја маскираат со пристапот: „етнографија 
како теорија“ или „практика“. Но, тоа исто така претставуваше практично неизбежен исход од внатрешните противречности во потрагата по голема „природна наука на општеството“. Многу е полесно да се види ретроспективно како постмодернизмот и кризата на претставеност резултираа со: реформулација на антрополошките практики, отфрлање на грандиозната голема теорија, редефинирање на поимот теорија и „повлекување во“ етнографија, па дури и повлекување од проектот на антропологијата. Како што забележува Хенриета Мур, овој натпревар - меѓу оние што тврдеа дека етнографијата е фикција и оние што тврдат дека е наука (Moore, 1999, 6) го карикатурирале внимателниот и втемелен начин на кој многу антрополози се обидувале да теоретизираат (уште еден термин користен во антрополошката наука) во тоа време. Постојат неколку набљудувања што можеме да ги направиме во врска со овие случувања, кои би можеле да ги групираме во два очигледно спротивставени тренда: еден (антитеорија и антинаука), оддалечувајќи се од позитивистичките и научно базираните идеи на теоријата, и втор (протеорија, но не и нужно пронаука - во тесна смисла на значењето), која ламентира по своето занемарување. Во однос на првиот тренд, повлекувањето во етнографијата, иако во својата најлоша самореференцијална, нејасна и ирелевантна форма, барем теоретизирањето, го премести на едно поинакво ниво на разбирање и толкување и нѐ принуди сериозно да размислуваме за квалитативните истражувачки практики и пишување. Големата теорија, со еден главен исклучок - Дарвинизмот во своите различни манифестации - е немодерна, додека од влијателниот преглед на Ортнер (Ortner, 1984), теориите станаа покомпозитни, парцијални и еклектични, поскоро може да се каже „понејасни“.

Постојат многу причини да се слави разноликоста, но она што некои го карактеризираат како „теоретска промена“, особено во последните четириесет години, всушност повеќе личи на „концептни метафори“ со огромни „сиви“ области на преклопување и двосмисленост меѓу различните парадигми. За Мур, целта на концептната метафора е да се „одржи двосмисленоста и продуктивната напнатост меѓу универзалните побарувања и специфичните историски контексти (Moore, 2004, 71), на пример: „глобално“, „пол“, „себство“, „тело“, или (во науката): „ум“, „мем“ или „мим“, „природа“. Ова се повеќе применливи „претпоставки“, еден вид концептуална скратувачка стимулативна мисла. Тие „дејствуваат како описен сјај или претставуваат причинско-последични сили, кои остануваат неистражени [и] во суштина страдаат од поттеоретизација“ (Moore, 2004, 80). Може да се спори дека она што важи за теорија во хуманистичките и општествените науки, е токму овој вид. Но што станува со „теоријата на уметноста“"?

Вториот тренд, очигледен од приближно доцните 80-ти години на минатиот век, се спротивстави на ова. Повлекувањето во етнографијата, емпиризмот и партикуларизмот сугерираше дека и антропологијата и археологијата биле „theory-lite“, односно се здобиле со погрдниот термин „лесна теорија“, па затоа и немаат соодветна научна строгост. Тоа беше расположението што доведе до основањето на „Групата за дебати во антрополошката теорија“ од 1987 година (Видете кај: Ingold, 1996) и до 
објавување серија книги за теоријата, во исто време. Исто така, во 2001 година се појави едно ново списание „Антрополошка теорија“.

Иако видот на теоретизирање беше далеку над конвенционалните модели на природната наука и честопати беше непријателски настроен кон неа, во некои аспекти порастот на пристапи засновани на науката може да се смета како дел од оваа реакција. Така, трендовите опишани во последните четириесет години парадоксално ги охрабрија и субверзијата и пролиферацијата на теоријата. Проблемите со експлицитно одобрување на посебни универзални теории, плус пост-постмодернистичкиот скептицизам, исто така ги охрабрија теориите во антропологијата, па „антрополошката теорија“ се повлекува во етнографијата. Навистина, се прашуваат некои антрополози, веројатно „веке не постои ниту една антропологија“, додека пак карактерот на „теоретското“ е ставено под знак прашање. Така теоријата стана прилично една ,разновидна група на критички стратегии што вклучува во себе критика на сопствените локации, позиции и интереси“ (Moore, 1999, 9, 18). Во зависност од личниот вкус, ова е или храбар нов свет на теоретска конфузија, целосно отфрлање на теоријата, или нешто од што нема излез. Што може да направи теоријата? Со оглед на овие контрадикторни трендови, присуството од изобилие на делумно рециклирани нови идеи и порастот на антитеоријата, треба да се види која е всушност функцијата на теориите.

Како прво, тие се рамка во која можат да се објаснат и да се интерпретираат податоците на еден што поекономичен начин. Рој Елен тврди дека теоријата може да се дефинира како „претпоставка или корпус на претпоставки со цел да ги објаснуваат феномените или податоците“ (Ellen, $1984,9)$. Но, Мур исто така генерално се согласува дека „теориите“ се богати со апстракција и по обем кога се споредуваат со други видови на генерализација, која е ниска по апстракција и по обем, а која произлегува од набљудувањето и од кое се поттикнати тие (Moore, 1999, 19). Некои теории едноставно ќе бидат концептни метафори и не треба да имаме проблем со тоа. Повеќето „теории“ во социокултурната антропологија не генерираат лесно проверливи хипотези или квалитативни корелации, делумно затоа што обидите за корелација во минатото ни покажаа колку е ова ризично и несигурно. Значи, ако ја поврземе „матрилинијата“ со статусот на жената, последователно откриваме дека матрилинијата не е 'предмет' и нејзините граници се нејасни. Тоа е она што нѐ предупредува да стоиме далеку од опасностите од симплистичкото квантифицирање и мерење и повеќе да се осврнеме на статистичките манифестации со поширок компаративистички потфат, како што е изработката на етнолошки атлас (на пр. Murdock, 1967).

Второ, каква и да е нивната форма, различните теории овозможуваат да се видат истите податоци на алтернативен начин, кои се всушност еднакви претстави, додека не се тестираат, наспроти податоците. Тие можат да бидат совршено интуитивни, но често се најкорисни кога се контраинтуитивни, пружајќи неочекувана перспектива за некои познати податоци, како во верзии на добро познатата наопаку свртена мапа. Без разлика дали ќе избереме една или друга теорија - квантна механика или теорија на брановите, теорија на размена или реципрочен алтруизам - со тоа ќе се утврди претставеноста и 
толкувањето на тие факти, но во согласност со доктрината за контрадикторните извесности во кога и двете позиции можат да бидат истовремено точни. Според тоа, теориите не се меѓусебно ексклузивни, ниту апсолутни; туку само подобри, полоши или едноставно различни претстави и објаснувања за нашите податоци.

Трето, теориите подразбираат методологија, но не се сосема иста работа. Значи еден проблем, со кој се соочуваме, веднаш на ова ниво на апстракција е како треба да ги разделиме двата термини кога, за жал, редовно се користат „теорија“ и „методологија“, кои значат различни работи за различни луѓe (Holzner, 1964, 425 - 426). Од една страна, методологијата е систематско проучување на принципите што го водат (во овој контекст) антрополошкото истражување и начините на кои теоријата ја наоѓ својата примена. Така, на пример, ако зборуваме за марксистичка методологија, етнометодологија, па дури и за дарвинистичка методологија, мораме да имаме на ум дека сите тие се гранка од философијата, која ги анализира принципите и процедурите на истражување во определена дисциплина, а исто така и систем на методи што се користат во таа дисциплина (Moore, 2004, 75).

Во ова време на таканаречен „животворен хаос“ почнаа да се отвораат нови патишта и канали, кои се покажаа како мошне привлечни за хуманистичката заедница. Со текот на времето, некои од овие патеки на истражување започнаа да се менуваат во разгазени патишта. Движењето на научната мисла во последните децении помина низ низа свртувања материјални, онтолошки, историски итн.

Тоа што се случува пред нашите очи може да се нарече враќање на постмодернизмот или критичко движење кон модернизмот, односно со други зборови, како каталогизирање и универзализација на едно ново ниво, како „нови пресврти и вртења, односно свртувања“, кои сугерираат согледување на други начини на научното движење и можат да се претворат во подлабока патека и тесна рамка за проектите од хуманистичните науки.

На крајот од втората декада на XXI век почнуваме да ги сфаќаме последиците од напуштањето на „големите теории“ и последиците од напуштањето на ова напуштање. Врз основа на стекнатите теоретски позиции вреди да се обидеме да се проучува еден така комплексен систем како што е, на пример, човечката култура. Во рамките на оваа тема се направи обид да се даде осврт на тековната методолошка состојба во фолклористиката и во сродните дисциплини со посебно внимание на проблемите што искрснуваат околу новите теории и перспективи.

\section{ЛИТЕРАТУРА}

ELLEN, R. F. (1984) (ed.) Introduction. In: Ethnographic research: a guide to general conduct.

FRIEDMAN, J. (1974). Marxism, structuralism and vulgar materialism. Man (N. S.) $9,444-69$.

HARRIS, M. (1969). The rise of anthropological theory: a history of theories of culture. London: Routledge \& Kegan Paul. 
HODDER, I. (2003). "Archaeology as a discontinuous domain". In: Essential tensions in archaeological method and theory (eds) T. L. Van Pool \& C. S. Van Pool, 5-9. Salt Lake City: University of Utah Press.

HOLZNER, B. (1964). "Methodology". In: A dictionary of the social sciences (eds.) J. Gould \& W. L. Kolb, 425-6. London: Tavistock.

INGOLD, T. (1996). Key debates in anthropology. London: Routledge.

Lowie, R. (1920). Primitive society. New York: Bonni \& Liveright.

Moore, H. L. (1999). "Anthropological theory at the turn of the century". In: Anthropological theory today (ed.) H. L. Moore, 1-23. Cambridge: Polity.

MOORE, H. L. (2004). "Global anxieties: concept-metaphors and pre-theoretical commitments in anthropology". Anthropological Theory 4, 71-88.

MURDOCK, G. P. (1967). Ethnographic atlas. Pittsburgh: University Press.

ORTNER, S. (1984). Theory in anthropology since the sixties. Comparative Studies in Society and History 26, 126-66.

REYNA, S. P. (2001). "Theory counts: (discounting) discourse to the contrary by adopting a confrontational stance". Anthropological Theory 1, 9-29.

STOCKING, G. (1968). Race, culture and evolution: essays in the history of anthropology. New York: Free Press.

TRIGGER, B. C. (2006). A history of archaeological thought. Cambridge: University Press.

Bone Velichkovski

\section{A BRIEF OVERVIEW OF THEORIES IN FOLKLORISTICS FROM TODAY'S PERSPECTIVE}

\section{Summary}

In the present paper, the author focuses his attention on what has been happening in the field of humanities in the last decades of the 20th century, which has been marked by a new perhaps most severe crisis of positivism, as a time of abandoning the "grand theories" and universal interpretive schemes, and with a brief overview of the current state of folklore and related disciplines in the world.

The identification of similarities and coincidences in anthropological, ethnological and folkloric works gave priority to the quest for original interpretations and "local knowledge", with particular attention to methodology, its own assumptions and research considerations. The linear view of cultural phenomena has changed with the emergence of dynamic links between all the factors of a complex network system.

A new era of cleansing of "ideological glasses" and apology of "new folkloricism" has emerged at the end of the last century that has also affected domestic humanistic knowledge. Escaping censorship, abandoning established approaches and well-known models of interpretation has become fertile ground for emerging fresh themes and perspectives of research, revealing the reality of the non-trivial.

At this time of so-called "life chaos" new roads and canals were opened which proved to be very attractive to the humanitarian community. Over time, some of these research paths have begun to change into trampled paths. The movement of scientific thought in recent decades has gone through a number of turns - material, ontological, historical, etc. 
What happens before our eyes can be called a return to postmodernism or as a critical movement towards modernism, in other words, as cataloging and universalizing to a new level, as "new twists and turns," which suggest the perception of other modes of the scientific movement and can turn into a deeper path and a narrow framework for humanities projects.

At the end of the second decade of the 21st century, we begin to understand the consequences of abandoning the "grand theories" and the consequences of abandoning this abandonment. Based on the theoretical positions we have acquired, it is worth trying to study such a complex system as, for example, human culture. Within this topic, an attempt has been made to address the current methodological situation in folklore and related disciplines with particular attention to the problems of new theories and perspectives. 